\section{Nauplius}

The Journal of The

Brazilian Crustacean Society

e-ISSN 2358-2936

www.scielo.br/nau www.crustacea.org.br
This article is part of the special series offered by the Brazilian Crustacean Society in honor to Ludwig Buckup in recognition of his dedication and contributions to the development of Carcinology

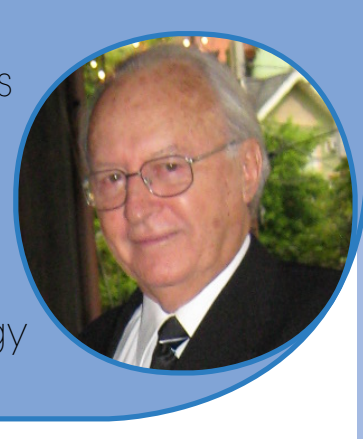

Original Article

\title{
Checklist of the species of Macrobrachium Spence Bate, 1868 (Decapoda: Caridea: Palaemonidae) from the lower Parnaíba River basin, Piauí, Brazil
}

Laira Lianos ${ }^{1,4}$ iD orcid.org/0000-0003-0560-3559
Michelle Mollemberg1,4 (D) orcid.org/0000-0001-6937-0841
Laurindo André Rodrigues ${ }^{2}$ iD orcid.org/0000-0002-7623-2663
Michelle Pinheiro Vetorelli3 ${ }^{\text {iD }}$ orcid.org/0000-0002-3114-3704
William Santana ${ }^{1,4}$ (DD orcid.org/0000-0003-3086-4419

1 Programa de Pós-Graduação em Zoologia, Universidade Estadual Paulista "Júlio de Mesquita Filho". Botucatu, São Paulo, Brazil.

LLE-mail: lahlianos@hotmail.com

MM E-mail: michelle.mollemberg@gmail.com

2 Núcleo de Pesquisa em Pesca e Aquicultura, Empresa Brasileira de Pesquisa Agropecuária - EMBRAPA Meio-Norte. Parnaíba, Piauí, Brazil..

LAR E-mail: laurindo.rodrigues@embrapa.br

3 Departamento de Ciências do Mar, Universidade Federal do Piauí, Campus Ministro Reis Veloso. Parnaíba, Piauí, Brazil.

MPV E-mail: mvetorelli@yahoo.com.br

4 Laboratório de Sistemática Zoológica, Universidade do Sagrado Coração. Bauru, São Paulo, Brazil..

ws E-mail: willsantana@gmail.com

ZOOBANK: http://zoobank.org/urn:lsid:zoobank.org:pub:A007546E-0EDE-414EA383-18E301B6FD29

\section{Abstract}

We present herein the results of a brieffield survey of species of Macrobrachium Spence Bate, 1868 in three points of the northern portion of the lower Parnaíba River basin. The northern region of the lower Parnaíba River basin is part of the Environmental Protection Area Delta do Parnaíba and 
comprises several lakes, coastal lagoons, and the delta of the Parnaíba River. In total, we found five species: Macrobrachium acanthurus (Wiegmann, 1836), Macrobrachium amazonicum (Heller, 1862), Macrobrachium carcinus (Linnaeus, 1758), Macrobrachium jelskii (Miers, 1877), and Macrobrachium olfersii (Wiegmann, 1836) all of which are new records for the region.

\section{KeY WORDS}

Palaemoninae, new record, freshwater prawn, distribution, Neotropical region.

\section{INTRODUCTION}

Macrobrachium Spence Bate, 1868 is a very successful group of palaemonid shrimps found in freshwater and estuarine habitats in the tropical and subtropical regions of the world (Holthuis, 1952; Valencia and Campos, 2007). Nowadays, Macrobrachium is considered the most speciose genus of the subfamily Palaemoninae, with 243 species, 55 of which are found in the Americas and 17 in Brazil (Fransen and De Grave, 2009; Pileggi and Mantelatto, 2012).

Macrobrachium shrimps are very important commercially, with several species fished and farmed around the world (Holthuis, 1980; Moraes-Riodades and Valenti, 2001). Likewise, they play an important role in the food chain and other ecological processes of the freshwater fauna (Magalhães, 2001). Nevertheless, information about some species is scarce, especially for those that are smaller and of little commercial interest and for species with restricted distributional areas and low abundance (Barros and Braun, 1997).

The northern portion of the lower Parnaíba River basin is part of the Environmental Protection Area Delta do Parnaíba, which comprises several lakes and coastal lagoons (ICMBIO, 2017). The costal region's peculiar conditions and diverse ecosystems led to the region's categorization as one of the priority areas for conservation actions as well as sustainable use and sharing of the Brazilian biodiversity (LIMA/ COPPE/UFRJ, 2006). However, the northeast region's freshwater biodiversity remains almost unexplored (Rocha, 2003), and the crustacean fauna in the habitats of the lower Parnaíba River basin is nearly unknown. We presented herein the results of a brief field survey of species of Macrobrachium in three points of the northern portion of the lower Parnaíba River basin, state of Piauí, Brazil.

\section{Material And Methods}

The sampling occurred from June 2012 to July 2014 in the Portinho Lagoon (02 $56^{\prime} 47.7^{\prime \prime}$ S 41 40'57.2”W), Parnaíba River delta region (02 49'54.5”S 41 49'48.7”W), and Prata Lagoon (02 58'41.5”S $41^{\circ} 47^{\prime} 05.2^{\prime} \mathrm{W}$ ) (Fig. 1). In Portinho Lagoon and the Parnaíba River, local fishermen collected the material. Using shrimp traps in overnight intervals, M.P. Vetorelli and L.A. Rodrigues collected the samples in the Prata Lagoon. They collected additional material of Macrobrachium carcinus (Linnaeus, 1758), in the delta of Parnaíba River on 22.iii.2018. The material was anesthetized with ice and preserved in $70 \%$ ethanol. The material is deposited in the collections of the Laboratório de Sistemática Zoológica (LSZ) of the Universidade do Sagrado Coração, Bauru, São Paulo, Brazil and the Coleção Zoológica Delta do Parnaíba (CZDP) of the Universidade Federal do Piauí, Parnaíba, Piauí, Brazil.

\section{Results}

In total, we found five species of Macrobrachium: Macrobrachium acanthurus (Wiegmann, 1836), Macrobrachium amazonicum (Heller, 1862), Macrobrachium carcinus, Macrobrachium jelskii (Miers, 1778), and Macrobrachium olfersii (Wiegmann, 1836), which represents a high degree of diversity if we consider that only 17 species can be found in Brazil (Pileggi and Mantelatto, 2012). Macrobrachium carcinus, M. acanthurus, and M. amazonicum have high potential for commercial exploitation and extraction by the communities living in the area (Valenti, 1985; Mantelatto et al., 2016).

It is important to notice that three (M. acanthurus, $M$. amazonicum, and M. olfersii) of the five species found in 

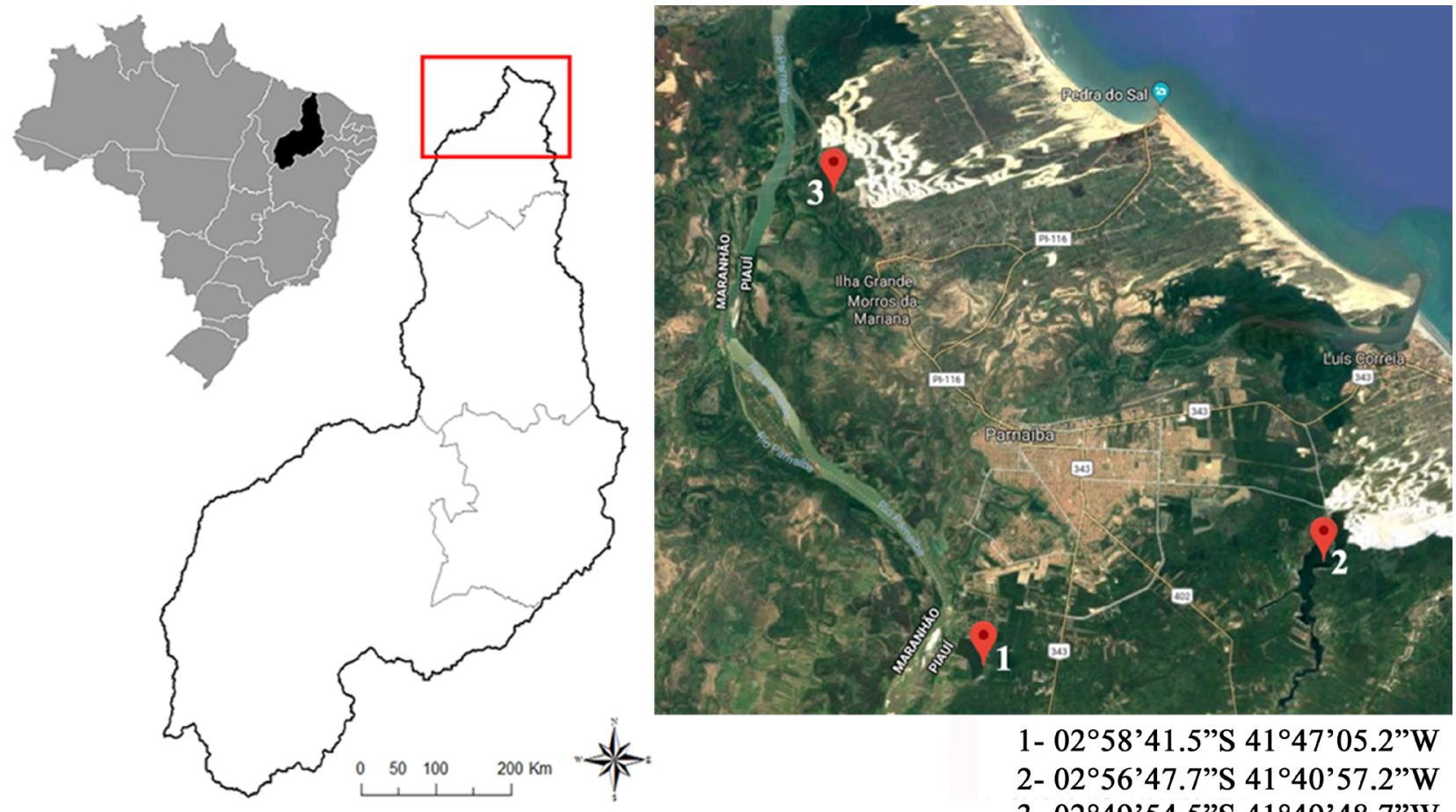

1- 02 ${ }^{\circ} 58^{\prime} 41.5^{\prime \prime S} 41^{\circ} 47^{\prime} 05.2^{\prime \prime} \mathrm{W}$

2- 02 ${ }^{\circ} 56^{\prime} 47.7^{\prime \prime} \mathrm{S} 41^{\circ} 40^{\prime} 57.2^{\prime \prime} \mathrm{W}$

3- 02 ${ }^{\circ} 49^{\prime} 54.5^{\prime \prime} \mathrm{S} 41^{\circ} 49^{\prime} 48.7^{\prime \prime} \mathrm{W}$

Figure 1. Map of Brazil indicating the state of Piauí and the Parnaíba River delta region. Sampling points marked in red dots: 1Prata Lagoon; 2- Portinho Lagoon; 3- Parnaíba River.

this work were collected in the Portinho Lagoon. Since 2015, however, this lagoon is passing through an intense process of drought, alternating dry periods with periods of very small amounts of water and compromising all local fauna (Amaral, 2015; Santana, 2018).

\section{Infraorder Caridea Dana, 1852}

\section{Palaemonidae Rafinesque, 1815}

Palaemoninae Rafinesque, 1815

Macrobrachium Spence Bate, 1868

\section{Macrobrachium acanthurus (Wiegmann, 1836)}

(Fig. 2A-D)

Material examined. Brazil, Piauí: Portinho Lagoon, ix.2013, 10 males, 8 females [CZDP (F2) 0056]. Idem, 20.ii.2014, 6 males, 8 females [CZDP (F2) 0058]. Idem, 15.v.2013, 1 male, 2 females (LSZ 0019). Prata Lagoon, 20.xii.2014, 3 males, 4 females [CZDP (F2) 0055].
Distribution. In Brazil, this species has been recorded in the states of Amapá, Pará, Maranhão, Piauí, Ceará, Rio Grande do Norte, Paraíba, Pernambuco, Alagoas, Sergipe, Bahia, Espírito Santo, Rio de Janeiro, São Paulo, Paraná, Santa Catarina and Rio Grande do Sul (Melo, 2003; Pimentel and Magalhães, 2014; present work).

Remarks. This is the first record of this species from the lower Parnaíba River basin and the northern portion of the state of Piauí, with only one documented previous record in the state from the municipality of Jaicós (Ferreira et al., 2010). This species can be differentiated from its congeners through a combination of characters of the rostrum and telson (Valencia and Campos, 2007): rostrum slightly sinuous and apex somewhat curved upward, usually overreaching scaphocerite; upper margin of rostrum with 8-12 teeth, with proximal teeth closer to each other, including 1-3 teeth completely postorbital; lower margin of rostrum with 4-7 teeth; telson terminal margin ending in sharp midpoint, with 2 pairs of spinules laterally, inner pair overreaching midpoint. 


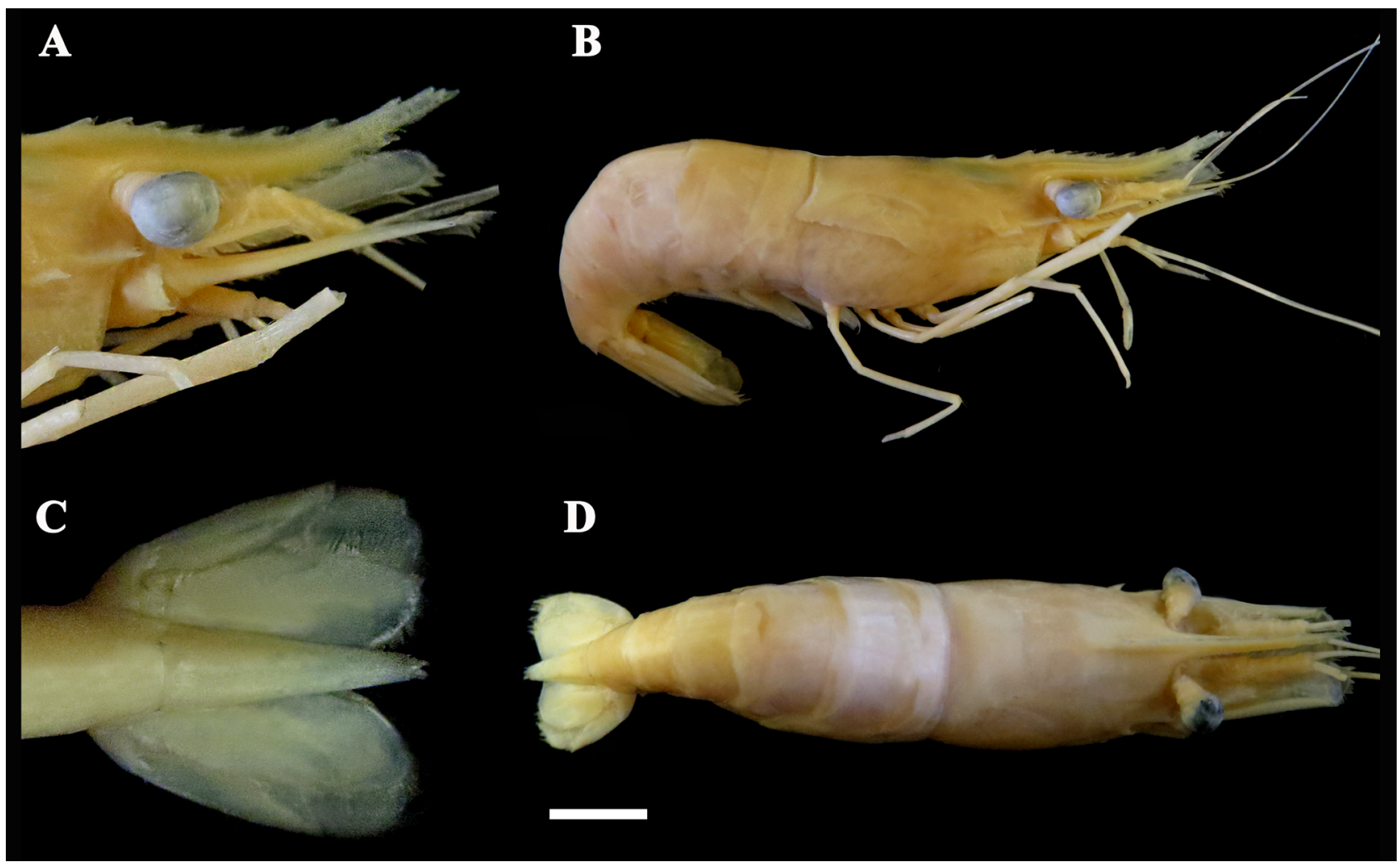

Figure 2. Macrobrachium acanthurus (Wiegmann, 1836), female (LSZ 019). A, Detail of the anterior region of the carapace; B, habitus, lateral view; C, detail of the telson and uropods, dorsal view; D, habitus, dorsal view. Scale bar: $1 \mathrm{~cm}$.

\section{Macrobrachium amazonicum (Heller, 1862)} (Fig. 3A-D)

Material examined. Brazil, Piauí: Portinho Lagoon, 20.ii.2014, 60 specimens [CZDP (F2) 0054]. Idem, 19.vii.2014, 65 specimens [CZDP (F2) 0060]. Idem, 19.vii.2014, 3 males (LSZ 030). Parnaíba River, 04.iii.2013, 40 specimens [CZDP (F2) 0057]. Prata Lagoon, 20.xii.2014, 100 specimens [CZDP (F2) 0059].

Distribution. In Brazil, this species has been recorded in the states of Acre, Roraima, Rondônia, Amapá, Amazonas, Pará, Maranhão, Piauí, Ceará, Rio Grande do Norte, Paraíba, Pernambuco, Bahia, Tocantins, Goiás, Mato Grosso, Mato Grosso do Sul, Minas Gerais, São Paulo and Paraná (Melo, 2003; Pileggi et al., 2013; Pimentel and Magalhães, 2014; present work).

Remarks. Ramos-Porto and Coelho (1998) as well as Melo (2003) cited the occurrence of M. amazonicum from Piauí, however, they did not mention the material examined and locality. This is the first record of $M$. amazonicum from the lower Parnaíba River basin.
According to Magalhães et al. (2005), adults of $M$. amazonicum are easily recognized by the long and sinuous rostrum, which is arched over the orbits and obliquely curved upward distally. Telson somewhat conical, tapering gradually toward to the tip, ending in an acute median point with no distinct discontinuity, with two pairs of spines in the posterior half of the lateral margins, inner pair not overreaching the apex of the telson. In immature and juvenile specimens these characters can be misleading, especially in comparisons with M. jelskii. However, the telson of $M$. jelskii have a distinct posterior margin, with a clear discontinuity between the lateral margins and the median point, and the inner pair of spines of the posterolateral margins is always longer than the median point of the telson (Magalhães et al., 2005).

\section{Macrobrachium carcinus (Linnaeus, 1758)}

(Fig. 4A-D)

Material examined. Brazil, Piauí: Parnaíba River, 23.iii.2018, 1 male [CZDP (F2) 0061], 1 male [CZDP (F2) 0062]. 


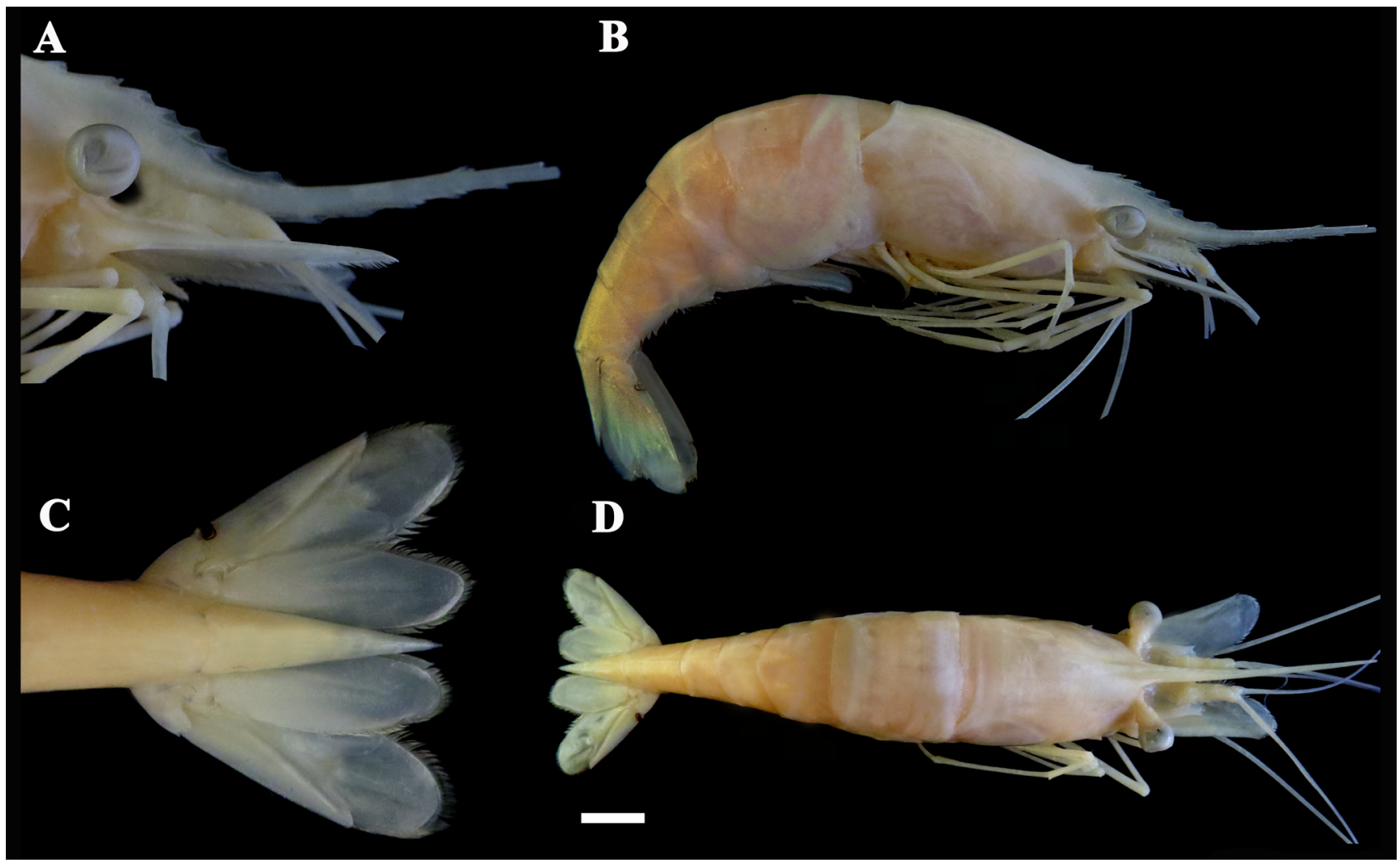

Figure 3. Macrobrachium amazonicum (Heller, 1862), male (LSZ 030). A, Detail of the anterior region of the carapace; B, habitus, lateral view; $\mathrm{C}$, detail of the telson and uropods, dorsal view; $\mathrm{D}$, habitus, dorsal view. Scale bar: $1 \mathrm{~cm}$.

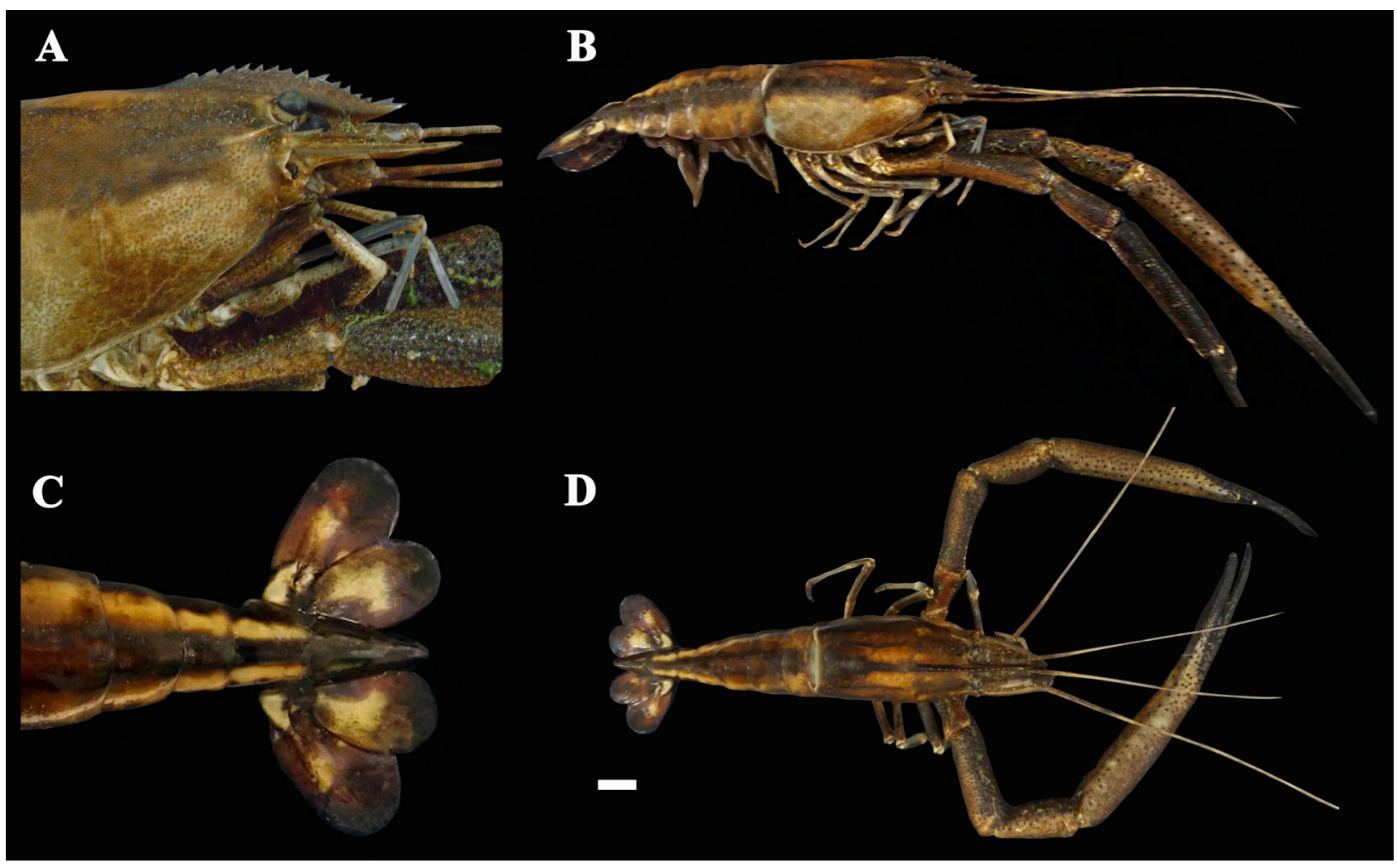

Figure 4. Macrobrachium carcinus (Linnaeus, 1758), male [CZDP (F2) 0061]. A, Detail of the anterior region of the carapace; B, habitus, lateral view; C, detail of the telson and uropods, dorsal view; D, habitus, dorsal view. Scale bar: $2 \mathrm{~cm}$. 
Distribution. This species is found in Brazil in the states of Amapá, Pará, Piauí, Pernambuco, Alagoas, Espírito Santo, Rio de Janeiro, São Paulo, Santa Catarina, Paraná and Rio Grande do Sul (Melo, 2003; Sampaio et al., 2009; Pimentel and Magalhães, 2014; present work).

Remarks. As for M. amazonicum, Ramos-Porto and Coelho (1998) and Ferreira et al. (2010) cited the occurrence of $M$. carcinus in Piauí but without mention the material examined and locality. This is the first documented record of M. carcinus in the Parnaíba River basin. Macrobrachium carcinus is the most important freshwater species economically and socially in the Brazilian northeast region. Populations of this species are in decline in several Brazilian hydrographic basins due to over-exploitation and habitat loss (Almeida et al., 2008). However, no studies about population estimation quantify the population reduction of this species, which motivated the categorization of this species as Insufficient Data in the last evaluation of the threatened crustacean species of the Brazilian fauna (Mantelatto et al., 2016), although most fishermen agree that this species is threatened in at least some regions (Almeida et al., 2008). In addition, the practice of uncontrolled cultivation of other Macrobrachium species in nonnative areas, with the possibility of species dispersal, may represent a future concern for local biodiversity (Mantelatto et al., 2016). Macrobrachium carcinus is easily recognizable through its short rostrum and the carpus of the second pereopod distinctly shorter than the merus, and with a single, large, triangular tooth on the cutting edges of the dactyl and propodus.

\section{Macrobrachium jelskii (Miers, 1778)}

(Fig. 5A-D)

Material examined. Brazil, Piauí: Prata Lagoon, 18.xi.2014, 500 specimens [CZDP (F2) 0049]. Idem, 18.xi.2014, 1 male, 4 females (LSZ 027).

Distribution. In Brazil, this species has been recorded in the states of Acre, Amapá, Amazonas, Pará, Maranhão, Piauí, Ceará, Rio Grande do Norte,

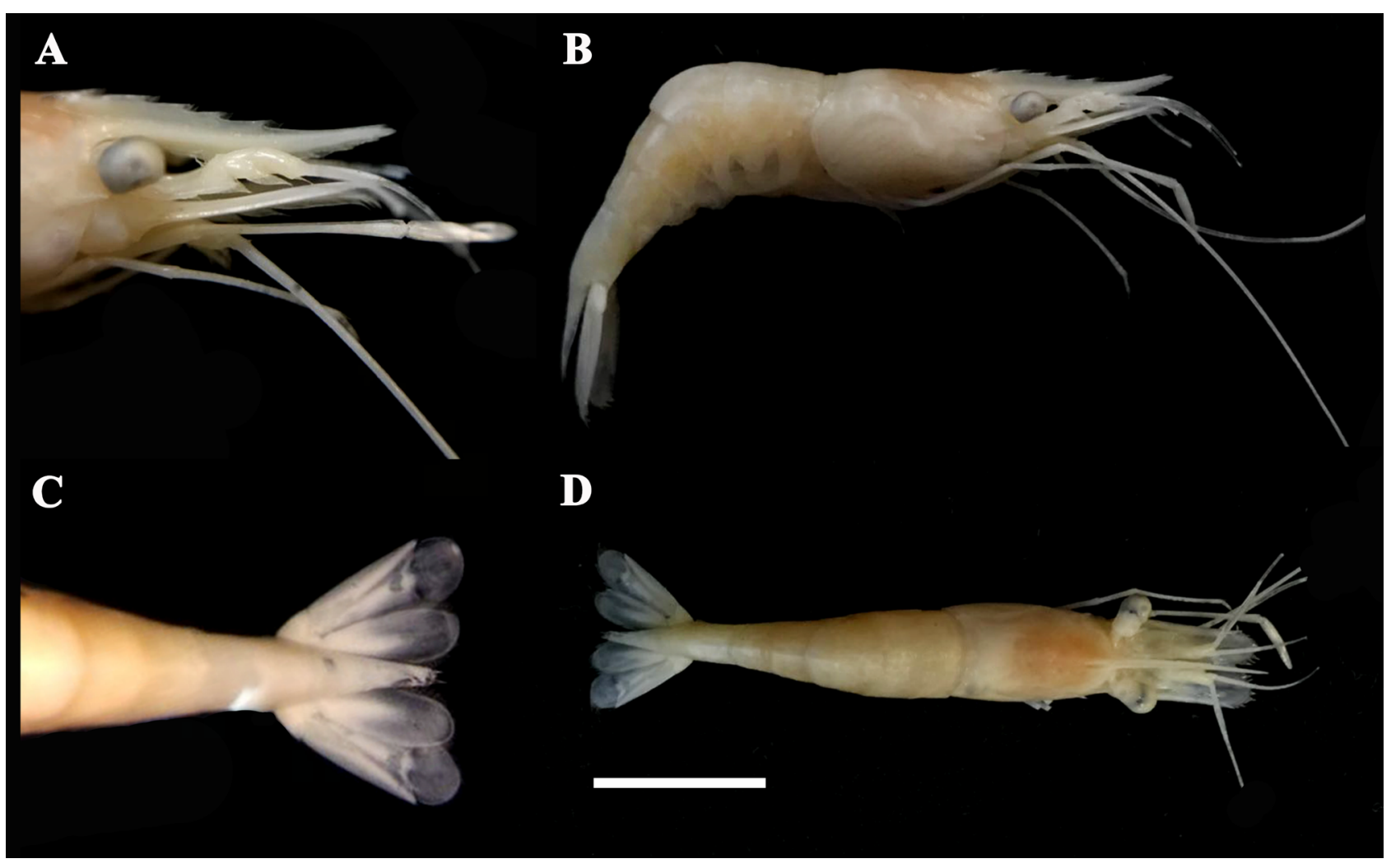

Figure 5. Macrobrachium jelskii (Miers, 1778), female (LSZ 027). A, Detail of the anterior region of the carapace; B, habitus, lateral view; C, detail of the telson and uropods, dorsal view; D, habitus, dorsal view. Scale bar: $1 \mathrm{~cm}$. 
Paraíba, Pernambuco, Alagoas, Sergipe, Bahia, Mato Grosso, Espírito Santo, Rio de Janeiro, Minas Gerais, São Paulo, Paraná, Santa Catarina) (Melo, 2003; Pileggi et al., 2013; present work).

Remarks. This is the first record of $M$. jelskii in the Parnaíba River basin. M. jelskii is commonly found in sympatry with $M$. amazonicum. Here we found both species in Prata Lagoon, though M. jelskii was more abundant than $M$. amazonicum (cf. material examined). Also, see remarks section regarding $M$. amazonicum for characters to differentiate between these species.

\section{Macrobrachium olfersii (Wiegmann, 1836)} (Fig. 6A-D)

Material examined. Brazil, Piauí: Portinho Lagoon, 25.iv.2013, 46 specimens [CZDP (F2) 0050]. Idem, 19.vii.2013, 38 specimens [CZDP (F2) 0051]. Idem, 20.ii.2014, 10 specimens [CZDP (F2) 0052]. Idem, 04.viii.2013, 46 specimens [CZDP (F2) 0053]. Idem, 19.vii.2013, 2 females (LSZ 075).

Distribution. In Brazil, this species has been recorded in the states of Amapá, Piauí, Ceará, Rio Grande do Norte, Alagoas, Sergipe, Bahia, Minas Gerais, Espírito Santo, São Paulo and Santa Catarina (Barros and Braun, 1997; Müller et al., 1999; Melo, 2003; Pimentel and Magalhães, 2014; present work).

Remarks. This is the first record of M. olfersii in the lower Parnaíba River basin, although Ferreira et al. (2010) mentioned the occurrence of this species in Piauí when discussing an indeterminate specimen from the Piauí River without a precise locality [material deposited at the Museu Nacional (MNRJ 2574)]. Macrobrachium olfersii can be easily differentiated through its almost straight and relatively short rostrum, and the strong second pair of pereopods with chelae of unequal sizes and gaping fingers and a dense pubescence on the palm and cutting edges.

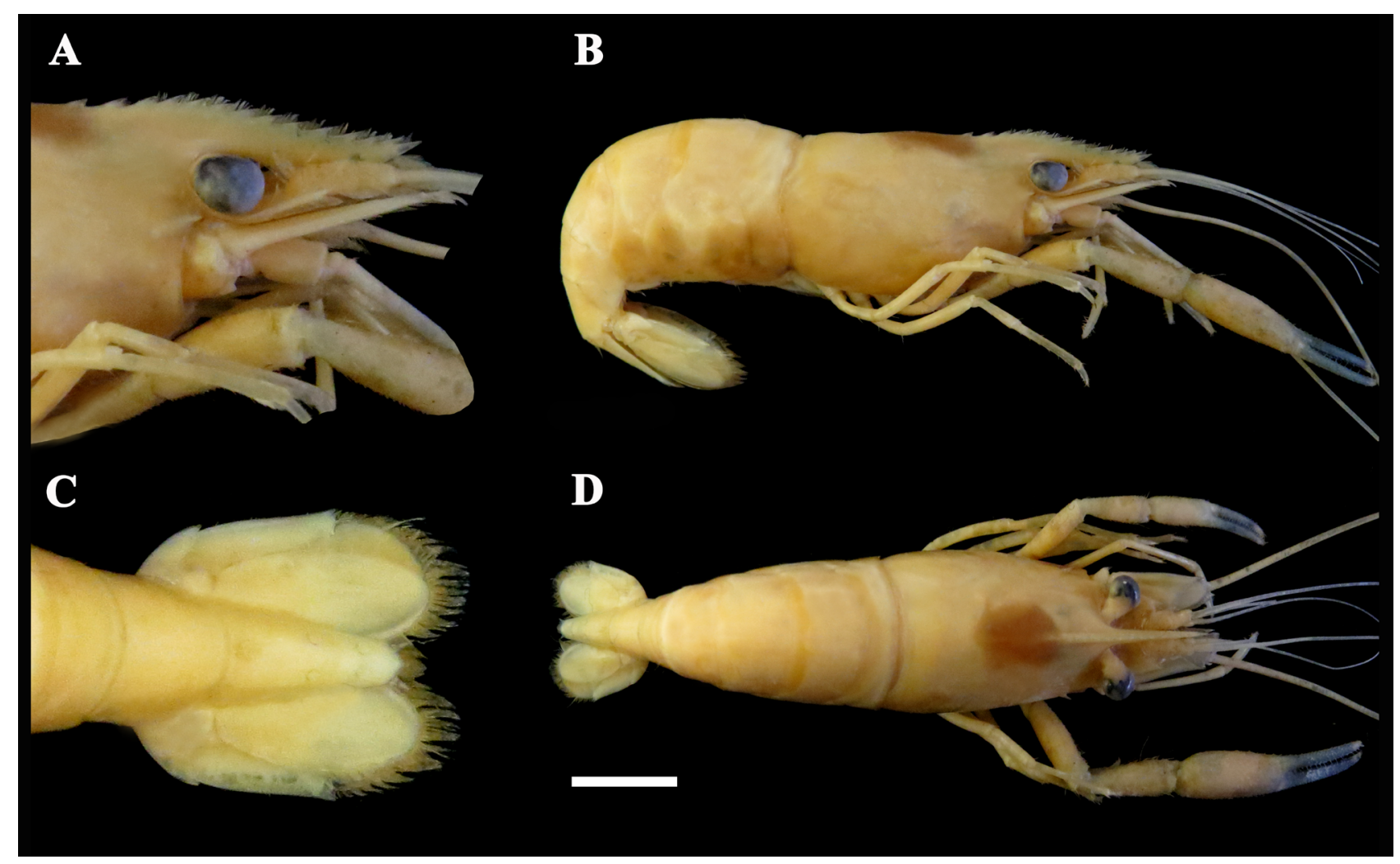

Figure 6. Macrobrachium olfersii (Wiegmann, 1836), female (LSZ 075). A, Detail of the anterior region of the carapace; B, habitus, lateral view; C, detail of the telson and uropods, dorsal view; D, habitus, dorsal view. Scale bar: $1 \mathrm{~cm}$. 


\section{ACKNOWLEDGEMENTS}

\section{LL, MM, and WS thank the Fundação de Amparo à} Pesquisa do Estado de São Paulo and the Universidade do Sagrado Coração for the support in the studies of decapod crustacean systematics. LAS and MV thank the Fundação de Amparo à Pesquisa do Estado do Piauí for the financial support provided. Thanks to Célio Magalhães and an anonymous reviewer for their valuable comments that helped to improve the manuscript.

\section{RefERENCES}

Almeida, A.O.; Coelho, P.A.; Luz, J.R.; Santos, J.T.A. and Ferraz, N.R. 2008. Decapod crustaceans in fresh waters of southeastern Bahia, Brazil. Revista de Biología Tropical, 56: 1225-1254.

Amaral, K. 2015. Pesquisador afirma que barragens secaram Lagoa do Portinho. Available at https: / www.meionorte.com/cidades/ pi/parnaiba/pesquisador-afirma-que-barragens-secaram-lagoado-portinho-310042. Accessed on 12 January 2018.

Barros, M.P. and Braun, A.S. 1997. Contribuição ao estudo dos Atyidae e Palaemonidae (Crustacea, Decapoda) do leste brasileiro $14^{\circ} 21^{\prime}$ e $21^{\circ} 55^{\prime}$ de latitude sul. Biotemas, 10: 7-26.

Ferreira, R.S.; Vieira, R.R.R. and D'Incao, F. 2010. The marine and estuarine shrimps of the Palaemoninae (Crustacea: Decapoda: Caridea) from Brazil. Zootaxa, 2606: 1-24.

Fransen, C.H.J.M. and De Grave, S. 2009. Evolution and radiation of shrimp-like decapods: an overview. p. 245-260. In: J.W. Martin; K.A. Crandall and D.L. Felder (eds), Decapod Crustacean phylogenetics. Crustacean issues, Vol. 18. Boca Raton, Taylor and Francis/CRC Press.

Holthuis, L.B. 1952. A general revision of the Palaemonidae (Crustacea, Decapoda, Natantia) of the Americas. II. The subfamilies Palaemonidae. Allan Hancock Foundation Publications: Occasional Papers, 12: 1-396.

Holthuis, L.B. 1980. FAO species catalogue. Shrimps and prawns of the world. An annotated catalogue of species of interest to fisheries, vol. 1. FAO Fisheries Synopsis, 125: 1-271.

ICMBIO. 2017. Unidades de conservação - Marinho: APA Delta do Parnaíba. Available at http://www.icmbio.gov.br/ portal/unidadesdeconservacao/biomas-brasileiros/marinho/ unidades-de-conservacao-marinho/2246-apa-delta-doparnaiba. Accessed on 05 December 2017.

LIMA/COPPE/UFRJ. 2006. Avaliação Ambiental Estratégica. Região Costa Norte - Linha de Base: Aspectos Ambientais. p. 136-231. Ministério do Meio Ambiente, Laboratório Interdisciplinar de Meio Ambiente.

Magalhães, C. 2001. Diversity, distribution, and habitats of the macro-invertebrate fauna of the Río Paraguay and Río Apa, Paraguay, with emphasis on Decapod Crustaceans. p. 68-72. In: B. Chernoff; P.W. Willink and J.R. Montambault (eds), A biological assessment of the aquatic ecosystems of the Río Paraguay Basin, Alto Paraguay, Paraguay. Washington, Conservation International. (RAP Bulletin of Biological Assessment, 19.)
Magalhães, C.; Bueno, S.L.S.; Bond-Buckup, G.; Valenti, W.C.; Silva, H.L.M.; Kiyohara, F.; Mossolin, E.C. and Rocha, S.S. 2005. Exotic species of freshwater decapod crustaceans in the state of São Paulo, Brazil: records and possible causes of their introduction. Biodiversity and Conservation, 14: 1929-1945.

Mantelatto, F.L.; Pileggi, L.G.; Magalhães, C.; Carvalho, F.L.; Rocha, S.S.; Mossolin, E.C.; Rossi, N. and Bueno, S.L.S. 2016. Avaliação dos Camarões Palemonídeos (Decapoda: Palaemonidae). p. 252-267. In: M.A.A. Pinheiro and H. Boos (eds), Livro Vermelho dos crustáceos do Brasil: avaliação 2010-2014. Porto Alegre, Sociedade Brasileira de Carcinologia.

Melo, G.A.S. 2003. Famílias Atyidae, Palaemonidae e Sergestidae. p. 289-415. In: G.A.S. Melo (ed), Manual de identificação dos Crustacea Decapoda de água doce do Brasil. São Paulo, Edições Loyola.

Moraes-Riodades, P.M.C. and Valenti, W.C. 2001. Freshwater prawn farming in Brazilian Amazonia shows potential for economic, social development. Global Aquaculture Advocade, 4: 73-74.

Müller, V.M.R.; Nazari, E.M.; Ammar, D.; Ferreira, E.C.; Beltrame, I.T. and Pacheco, C. 1999. Biologia dos Palaemonidae (Crustacea, Decapoda) da bacia hidrográfica de Ratones, Florianópolis, Santa Catarina, Brasil. Revista brasileira de Zoologia, 16: 629-636.

Pileggi, L.G. and Mantelatto, F.L. 2012. Taxonomic revision of doubtful Brazilian freshwater shrimp species of genus Macrobrachium (Decapoda, Palaemonidae). Iheringia, Série Zoologia, 102: 426-437.

Pileggi, L.G.; Magalhães, C.; Bond-Buckup, G. and Mantelatto, F.L. 2013. New records and extension of the known distribution of some freshwater shrimps in Brazil. Revista Mexicana de Biodiversidad, 84: 563-574.

Pimentel, F.R. and Magalhães, C. 2014. Palaemonidae, Euryrhynchidae, and Sergestidae (Crustacea: Decapoda): Records of native species from the states of Amapá and Pará, Brazil, with maps of geographic distribution. Check List, 10: 1300-1315.

Ramos-Porto, M. and Coelho, P.A. 1998. Malacostraca. Eucarida. Caridea (Alpheoidea excluded). p. 325-350. In: P.S. Young (ed), Catalogue of Crustacea of Brazil. Rio de Janeiro, Museu Nacional.

Rocha, O. 2003. Avaliação do estado do conhecimento da diversidade biológica do Brasil: Águas doces, versão preliminar. São Carlos, Ministério do Meio Ambiente, 70p.

Sampaio, S.R.; Nagata, J.K.; Lopes, O.L. and Masunari, S. 2009. Camarões de águas continentais (Crustacea, Caridea) da Bacia do Atlântico oriental paranaense, com chave de identificação tabular. Acta Biológica Paranaense, 38: 11-34.

Santana, B. 2018. Lagoa do Portinho foi perdida para sempre? Available at http://www.tribunadeparnaiba. com/2018/02/19/lagoa-do-portinhoi-perdida-para-sempre/. Accessed on 12 January 2018.

Valencia, D. and Campos, M.R. 2007. Freshwater prawns of the genus Macrobrachium Bate, 1868 (Crustacea: Decapoda: Palaemonidae) of Colombia. Zootaxa, 1456:1-44.

Valenti, W.C. 1985. Cultivo de camarões de água doce. São Paulo, Editora Nobel, 82p. 